\title{
A university evaluation of the Patricia Roberts Harris fellowship program for traditionally under-represented graduate students
}

\author{
Carole Katz, Maurice Daniels, Bruce A. Thyer and Tracey D. Ford \\ School of Social Work, The University of Georgia \\ College of Social Work, Florida State University \\ Office of Institutional Diversity, The University of Georgia
}

\begin{abstract}
Recent court decisions have challenged the legal viability of fellowship programs for traditionally underrepresented students and other affirmative action programs in higher education. These programs are one of several structural innovations designed to enhance campus diversity, to increase educational opportunity, and to assist in making available the benefits of master's level and professional study education programs to women and individuals from minority groups who are underrepresented in these programs. The Patricia Roberts Harris Fellowship Program (PRHFP) at the University of Georgia (UGA) was an example of such a program. This article reports the results of a descriptive, exploratory study that surveyed 17 former fellows of the UGA PRHFP to assess their evaluation of the effectiveness of the program in helping them attend and remain in graduate school, and in helping them find professional positions in their field of interest. Results indicated that this program was critical in helping recruit and retain traditionally underrepresented graduate students as well as helping them achieve their educational and professional goals.
\end{abstract}

Keywords: Affirmative Action, Minority Fellowship Program, Recruitment, Retention

\section{INTRODUCTION}

In the late 1960s, as a result of the gradual elimination of racially discriminatory barriers to higher education, more African American and other minorities began attending traditionally white colleges and universities, although progress was decidedly uneven (Lehner, 1980). As affirmative action programs were launched in an effort to achieve social justice in higher education with an increase in the availability of financial aid-scholarships, fellowships and grants, there were notable gains in the enrollment of blacks and other minority students in higher education (Olson, 1988). However, in recent years the recruitment and retention of African American students has become an issue of national concern in the wake of the erosion of programs designed to increase their enrollment in higher education, especially graduate school. According to Nettles (1990, p. 495), "Black and Hispanic students have been severely under represented among graduate students and doctoral degree recipients in the United States". Black student participation in higher education declined in the early 1980s, after several decades of increases (Love, 1993). In 1990, for example, even though blacks represented over $12 \%$ of the United States population and Hispanics $9 \%$, they represented 4.9 and $2.6 \%$, respectively, of master's degrees conferred by institutions of higher education, and 4.2 and $2.5 \%$, respectively, of earned doctorates (Statistical Abstract of the United States: 2001, Digest of Education Statistics, 2001).

By 2000 , the percentages of blacks and Hispanics in the U.S. population slightly increased, 12.8 and $11.8 \%$, respectively, and they made modest gains as graduate degree recipients. However, they continued to be grossly underrepresented among students earning graduate degrees in proportion to their percentage of the population. For example, in 19992000, blacks and Hispanics earned only 6.6 and $3.8 \%$, respectively, of earned doctorates. (Statistical Abstract of the United States, Digest of Education Statistics, 2001). Even though blacks and Hispanics have made gains in graduate enrollment and graduation rates since the early 1990s, the gains must be examined within the context that these groups have been historically under-represented in graduate schools. Their gains are simply a matter of continuing to catch up with their white counterparts.

While larger numbers of African American students enroll in higher education today, their graduation rates lag far behind their white counterparts. While black students in historically black colleges graduate at about the same rate as their white counterparts in 
Am. J. Soc. Mgmt. Sci., 2011, 2(1): 108-115

predominantly white institutions (Noel, Levitz \& Saluri, 1985), black attrition rates at white colleges are 5 to 8 times higher than those for white students on the same campuses (McCauley, 1988). Since up to $80 \%$ of black students in higher education are enrolled in predominantly white institutions (PWIs), this creates a major problem. Love (1993, p. 28) states "that at Historically Black Institutions (HBIs) black students feel welcomed and comfortable to learn, while at PWIs, the experience of black students is far from comfortable." The National Advisory Committee on Black Higher Education and Black Colleges and Universities contends that systemic and institutional barriers in graduate and professional education persist because there is little direction from the Federal government on equal opportunity. Moreover, the advisory committee states that the failure of blacks "to attain equity in graduate and professional education is a direct result of the decline in Civil Rights incentives." Notwithstanding the recent U. S. Supreme Court decision in Grutter $v$. Bollinger, which appears to provide a limited legal framework for affirmative action programs in higher education, the federal government has been consistently moving toward the dismantling of those laws and programs that undergirded the civil rights agenda of the 1960s and 1970s. (Grutter v. Bollinger, 2002; Wilson, 1988)

Comparative analyses of the experiences of black students attending predominantly black and white institutions reveal that students in PWIs report that racial discrimination occurs with greater frequency (Allen, 1988). A number of studies have sought to identify specific factors that affect dropout rates among black students at PWIs, and Love (1993) has catalogued 7 factors from this literature which appear to influence the retention of black students: white racism; finances; social interaction, cultural dissonance \& environmental congruence; interaction with faculty; student services; and student characteristics. A study by Allen (1981) found that good academic performance and persistence correlate with a positive racial environment on campus. While numerous studies have been conducted pertaining to the differential success of black undergraduate students in historically black and predominantly white colleges, relatively fewer studies have been done of differential graduate and professional study (Wilson, 1988, p. 166). However, one study of African American graduate and professional students, enrolled in six universities in different sections of the country in 1981, identified several problems confronting minority students in majority white schools and found that finances are a major problem for minority students (Hall \& Allen, 1983). These authors also found that substantial numbers of these students rarely participated in black-sponsored organizations on campus, and that their academic achievements seemed to be closely tied to the availability of mentoring relationships with faculty. The frequency and quality of the interactions students have with faculty and mentors in graduate school and their socializing with peers have been found to be more important determinants of graduate school success than their personal characteristics, or their undergraduate experiences (Blackwell, 1987; Harnett, 1976). Patterson-Stewart, Ritchie and Saunders (1997, p. 489) found that "graduate students and graduate degree recipients perceive their relationship with faculty and mentors as well as peer socialization, to be critical to their satisfaction and successful completion of graduate programs." The following two quotations are representative of the issues facing racial minority students attending PWIs:

"Persistence needed for successful completion of the graduate school process has more to do with noncognitive personal variables such as feelings, attitudes, perceptions of the institutional climate, faculty, professional staff, and peer groups more so than with academic difficulties." (Patterson-Stewart, Ritchie \& Saunders, 1997, p. 489).

"Negative attitudes and racist stereotypes combined with overt racial threats and violence by white students create many problems forcing black students to leave school prior to graduation. These underlying attitudes seem not to have changed over time." (Love, 1993, p. 29).

The inability to feel integrated into the mainstream of academic life under these adverse conditions contributes to the black student's sense of alienation, which in turn is acted out in a variety of subtle ways reflecting the student's perception of racism.

The Patricia Roberts Harris Fellowship Program (PRHFP) at the University of Georgia (UGA) was a federally funded program sponsored by the U.S. Department of Education which provided fellowships to women and minority students pursuing masters, doctoral and professional-level studies in academic fields in which they are underrepresented, and for careers that serve the public interest (Daniels, Johnson \& Tomlinson, 1996). The federal government annually set priority fields of study, based on national need. To support the recruitment 
and retention of minority students, special services were implemented. "Critical components that contribute to the success of the PRHFP include innovative approaches to recruitment, mentorships, peer support, networking opportunities, academic support programs, and the establishment of PRHFP student assistantships and awards"(Daniels, Johnson \& Tomlinson , 1996, p. 251).

Recent court decisions have challenged the legality of minority fellowship programs and other affirmative action programs in higher education. These state and national programs were one of several structural innovations designed to enhance campus diversity, to increase educational opportunities for groups of students traditionally excluded from colleges and universities, and promote the recruitment and retention of these students. It was commonly accepted that affirmative action programs such as the PRHFP were effective at increasing the participation of minorities and women in higher education, and in moving them into gainful employment in education and industry. The American Council on Education's Minorities in Higher Education Annual Status Report (1995-1996) reported that "although these individual programs have proven successful, few have adequately documented their results"(ACE, 1996, p.8).

The second author served as the Project Director of the UGA's PRHFP during the years 1986 - 1997. In an effort to evaluate the results of this program, the authors developed an evaluation survey which was distributed to current students and alumni supported by the program from 1986 through 1997, and the findings are now reported.

\section{METHOD}

Participants and Program: The PRHFP awarded a total of 35 PRHFP fellowships (tuition waiver and monthly stipend) to graduate or professional students during the years 1986-1997, some of whom were enrolled when this study was undertaken. (In addition to PRHFP fellows who received tuition waivers and stipends, the PRHFP provided academic support, partial financial assistance, and research opportunities to a wide spectrum of students who did not receive full fellowships. The latter students were not included in this follow-up study).

The core of the program consisted of the following elements: 1. Providing a graduate fellowship and tuition waiver, 2. Linking each student to an academic faculty mentor, 3. Providing PRHFP students with a special orientation to the program and to the UGA, 4. Special innovative efforts made to recruit minority students to the program, 5 . Providing an academic tutor, as needed, 6 . Supporting a Graduate and Professional Scholars association, that connected PRHFP fellows with peer graduate and professional students, 7. Attempts made to promote a sense of peer support among and between each year's cohort of fellows, and 8. An ongoing series of workshops and seminars provided to PRHFP students that covered topics such as Study Strategies and Test-taking Skills, Enhancing Computer Literacy, Applying for Research Grants, Professional Development, Improving One's Networking Skills, and Ethnic and Cultural Issues at the UGA.

These services were provided to new graduate and professional students during their first and each subsequent year of their enrollment at the UGA, until graduation. The UGA PRHFP evolved over time, and not all the services listed above were available from the inception of the program.

Survey Development: We prepared a 3-part, 24item questionnaire involving both quantitative and qualitative responses, as well as providing demographic information. The quantitative questions were rated on a 5 point Likert scale $(1=$ no value or very poor; $2=$ little value or poor; $3=$ some value or fair; $4=$ considerable value or good, and $5=$ of extreme value or excellent). The qualitative component consisted of open-ended questions where the respondents could answer in their own words. The survey examined overall satisfaction with the PRHFP by participants, satisfaction with specific program components, and the degree to which fellows utilized various program components.

Design and Procedure: We mailed the survey to each current PRHFP student and alumnus $(\mathrm{N}=35)$ for whom we had contact information. A return envelope with postage was included along with a cover letter explaining the purposes of the study, protections of respondent confidentiality, and instructions for completing the survey. We attempted to contact each potential participant by phone to find out if $\mathrm{s} / \mathrm{he}$ had completed and returned the survey. If they had not, they were urged to do so and another questionnaire was mailed to them if necessary. A final attempt was made to contact respondents by telephone that had not responded to the mail survey and they were asked to complete the interview over the telephone at that time. 


\section{RESULTS}

We were able to contact 18 of 35 potential participants. One of the 18 refused to participate and 17 could not be located. Thus our responding group consisted of 17 of 35 (49\%) current PRHFP students or alumni. The demographic characteristics of our sample are presented in Table 1.

Table 1. Selected Demographic Characteristics of PRHFP Respondents at the University of Georgia.

\begin{tabular}{|l|l|l|l|}
\hline Variable & $\mathrm{N}(\%)$ & $\mathrm{N}(\%)$ & \\
\hline Gender & Male & Female & $10(59 \%)$ \\
& $7(41 \%)$ & Hispanic & \\
Ethnicity & Black & $16 \%)$ & \\
$\begin{array}{l}\text { Type of } \\
\text { Undergraduate } \\
\text { Institution } \\
\text { Attended }\end{array}$ & Predominantly & Predominantly & \\
$\begin{array}{l}\text { Gender } \\
\text { Makeup } \\
\text { of } \\
\text { Undergraduate } \\
\text { Institution }\end{array}$ & Male & Black & \\
$\begin{array}{l}\text { Degree } \\
\text { Objective }\end{array}$ & $4(23 \%)$ & $4(25 \%)$ & \\
\hline
\end{tabular}

About $40 \%$ of the respondents had found employment in an educational institution (e.g., college or university) after graduation, while $20 \%$ went to work in business and industry and another $20 \%$ were employed in a government agency of some kind. Post-graduation, PRHFP participants found employment in a fairly short period of time after graduation, about 3.5 months, and reported earning a mean gross salary of about $\$ 34,400$ per year.
Respondents were asked in the survey to give the UGA PRHFP program an overall rating and also to rate several specific goals of the program (note that not all 17 respondents answered every question). The ratings for the overall quality of the UGA PRHFP were quite positive, with $6(43 \%)$ as Good, and 8 $(57 \%)$ as Excellent. When asked to judge the adequacy of the PRHFP in terms of helping them to meet their career goals, 8 (47\%) participants rated it as Good and $9(53 \%)$ as Excellent. When asked to estimate their personal chances of attending graduate school without the PRHFP, 5 (29\%) reported Very Poor, $5(29 \%)$ as Fair, 6 (35\%) as Good, and $1(6 \%)$ as Excellent. When asked to estimate their chances of finding their present employment position without the PRHFP, 2 (15\%) gave a rating of Poor, 2 (15\%) as Poor, 7 (54\%) as Good, and $2(15 \%)$ as Excellent.

Respondents were next asked to report the value of each of several components of the PRHFP. Table 2 displays the results to these items. As the data clearly indicate, the Graduate Assistantship and tuition waiver was the component rated the highest by Fellows, with a mean 4.5 ranking, while having a mentor, peer support, and special recruitment all have a mean ranking of around 3. Providing a special orientation session for PRH Fellows was next with a mean of just under 3 , followed by having an academic tutor at around 2.75. Attending meetings of the Graduate and Professional Scholars association was rated lowest by program participants, with a mean score of just at 2 .

PRHFP participants were asked to indicate how well they were treated by administrators and students from within the PRHFP, as well as how well they were treated within their own individual graduate department by administrators and students. These data are displayed in Tables 3 and 4 . Fellows felt they were treated better by PRHFP personnel than they were by personnel within their own departments. 
Table 2. Respondents' Ratings of Specific Components of the PRHFP at the University of Georgia [N and (\%)]

\begin{tabular}{|c|c|c|c|c|c|}
\hline Variable & No Value & Little Value & Some Value & $\begin{array}{c}\text { Considerable } \\
\text { Value }\end{array}$ & $\begin{array}{l}\text { Extreme } \\
\text { Value }\end{array}$ \\
\hline $\begin{array}{l}\text { Graduate Assistantship } \\
\& \text { Tuition Waiver }\end{array}$ & 0 & 0 & $1(6 \%)$ & 1(6\%) & $14(87 \%)$ \\
\hline $\begin{array}{l}\text { Having an } \\
\text { Academic Tutor }\end{array}$ & $2(15 \%)$ & $2(15 \%)$ & $2(15 \%)$ & $2(15 \%)$ & $5(39 \%)$ \\
\hline $\begin{array}{l}\text { Attending a Special } \\
\text { Orientation for } \\
\text { PRHFP Participants }\end{array}$ & $1(8 \%)$ & 0 & $5(42 \%)$ & $4(33 \%)$ & $2(17 \%)$ \\
\hline $\begin{array}{l}\text { Attending Meetings of } \\
\text { the Graduate and } \\
\text { Professional Scholars } \\
\text { Association }\end{array}$ & $2(14 \%)$ & $1(7 \%)$ & $5(36 \%)$ & $4(29 \%)$ & $2(14 \%)$ \\
\hline $\begin{array}{l}\text { Peer Support } \\
\text { Provided by the } \\
\text { PRHFP }\end{array}$ & $1(7 \%)$ & 0 & $5(33 \%)$ & $3(20 \%)$ & $6(40 \%)$ \\
\hline $\begin{array}{l}\text { Special Recruitment } \\
\text { Methods to Identify } \\
\text { Minority Students }\end{array}$ & $1(8 \%)$ & 0 & $4(33 \%)$ & $4(33 \%)$ & $3(25 \%)$ \\
\hline $\begin{array}{l}\text { Having an Academic } \\
\text { Tutor }\end{array}$ & $2(33 \%)$ & $1(17 \%)$ & $2(33 \%)$ & 0 & $1(17 \%)$ \\
\hline
\end{tabular}

Table 3. Responses to "How Were You Treated by PRHFP Participants?" [N(\%)]

\begin{tabular}{|c|c|c|c|}
\hline Participant & Fair & Good & Excellent \\
\hline \multirow{2}{*}{$\begin{array}{l}\text { Director of the } \\
\text { PRHFP }\end{array}$} & 0 & 0 & $17(\%)$ \\
\hline & & & \\
\hline \multirow{2}{*}{$\begin{array}{l}\text { Other Faculty } \\
\text { Associated with } \\
\text { the PRHFP }\end{array}$} & $5(30 \%)$ & $8(47 \%)$ & $4(24 \%)$ \\
\hline & & & \\
\hline \multirow{2}{*}{$\begin{array}{l}\text { Other PRHFP } \\
\text { Fellows }\end{array}$} & $1(6 \%)$ & $5(29 \%)$ & $11(65 \%)$ \\
\hline & & & \\
\hline \multirow{2}{*}{$\begin{array}{l}\text { PRHFP Support } \\
\text { Staff }\end{array}$} & $1(6 \%)$ & $7(41 \%)$ & $9(53 \%)$ \\
\hline & & & \\
\hline \multirow{2}{*}{$\begin{array}{l}\text { Your Academic } \\
\text { Mentor }\end{array}$} & $2(18 \%)$ & $2(18 \%)$ & $7(64 \%)$ \\
\hline & & & \\
\hline
\end{tabular}

Table 4. Responses to "How Were You Treated by Members of Your Graduate Department?" [N(\%)]

\begin{tabular}{|c|c|c|c|c|c|}
\hline Participant & Very Poor & Poor & Fair & Good & Excellent \\
\hline \multirow{2}{*}{$\begin{array}{l}\text { Dean/ } \\
\text { Dept. Head }\end{array}$} & 0 & $1(6 \%)$ & $5(31 \%)$ & $7(44 \%)$ & $3(19 \%)$ \\
\hline & & & & & \\
\hline Other Faculty & 0 & $1(6 \%)$ & $9(53 \%)$ & $4(24 \%)$ & $3(18 \%)$ \\
\hline \multirow{2}{*}{$\begin{array}{l}\text { Other UGA } \\
\text { Graduate } \\
\text { Students }\end{array}$} & 0 & 0 & $5(29 \%)$ & $8(47 \%)$ & $4(24 \%)$ \\
\hline & & & & & \\
\hline \multirow{2}{*}{$\begin{array}{l}\text { Departmental } \\
\text { Support Staff }\end{array}$} & $1(6 \%)$ & 0 & $2(12 \%)$ & $7(41 \%)$ & $7(41 \%)$ \\
\hline & & & & & \\
\hline
\end{tabular}

All 17 participants rated the Director of the PRHFP as excellent, by far the highest favorable rating. No respondents reported treatment of very poor or poor by any of the individuals rated in the PRHFP. The mentors received the next highest rating, followed by 
program support staff and other faculty. Other faculty received the lowest mean rating among the PRHFP rated, although only $29 \%$ rated their treatment by other faculty as only 'fair'. Forty-seven \% rated treated by other faculty as 'good' and $23 \%$ rated treatment by other faculty as excellent. The rating for faculty and staff from the fellows' individual departments were generally lower than those of individuals from the PRHFP, but few fellows offered ratings of 'very poor' or 'poor'. Eighty-two percent of the fellows rated support staff from their department as either excellent or good, $62 \%$ rated the graduate department dean or head as excellent or good, and $70 \%$ rated other students in the department as excellent or good. Other faculty in the department received the lowest rating with $41 \%$ providing a rating of excellent or good. On balance, the Fellows reported being well treated by both PRHFP staff and by the faculty and staff of their affiliated graduate or professional departments.

Four open-ended questions were asked of $\mathrm{PRH}$ Fellows. Fellows were asked if they had experienced racism while a student at the University of Georgia. Just over $53 \%$ indicated that they had. A follow-up question asked Fellows who had indicated they had been exposed to racism to detail what incidents of racism they had experienced. In two cases the respondent reported that racism encountered was from a faculty member while in another case racism was reported by a staff person. Two respondents mentioned incidents relating primarily to classmates.

A second item asked PRH Fellows what they felt was the greatest strength of the Fellowship Program. Six respondents mentioned either the Director of the Fellowship program or program staff or administrator, while 5 more Fellows mentioned the financial assistance provided by the program. Responses included the mentoring process, peer support, empowerment, and relationships with other fellows.

Discussion and Implications: The PRH Fellowship program incorporated many of the academic support features which prior experience and research has demonstrated to be helpful in facilitating the success of graduate students from historically underrepresented groups, particularly minorities of color. Among these factors are specific elements intended to promote student-faculty interactions (Cole, 2008), student social capital (Palmer \& Gasman, 2008), student support networks (Grier-Reed, Madyun \& Buckley, 2008; Williams, 2002), and augmented academic tutoring in difficult subjects (Davis \& Sutherland, 2008; Palmer, Davis \& Thompson, 2010). The financial support provided under the auspices of the PRHFP was also a strong contributing factor to its success.

Our study is not without limitations. We reported results from a limited sample of historically underrepresented graduate students from a single large university, which limits the generalizability of our findings, for example. However, the study of former fellows of the PHRFP, although limited in number, reveals many of the same issues found in the literature. It does tell us the perceived effects of the graduate experience on a particular group of students. A large majority of the respondents rated the overall program as good to excellent. From the survey it is apparent that this program was important in providing financial and academic support, including help related to meeting career goals. The fellowship money was the highest rated component of the program. A majority rated their chances of attending graduate school without the fellowship money as fair to poor. These findings are consistent with the literature identifying finances as one of the issues affecting the retention of African American students. A higher percentage of minority students come from lower socioeconomic backgrounds as compared to their white counterparts. Often they will be among the first in their family to complete college or go on to an advanced degree. Financial difficulties can, therefore, be expected.

All the respondents obtained employment in their fields of interest. These jobs paid well with an overall gross mean salary of over $\$ 35,000$ per year. They were able to find their jobs in a relatively short time after completion of the program. They rated the program very highly in helping them meet their career goals. However, it was interesting to note that a majority felt that their chances of finding their present job without the fellowship were good to excellent.

Having an academic mentor, peer support, and special minority recruitment followed receiving fellowship money as the most important components of the program. This is not surprising as research has shown that the frequency and quality of interactions students have with faculty and mentors in graduate school and their socializing with peers are important determinants of graduate school success.

One surprising finding is the fact that relatively few of 
the respondents took advantage of the special workshops and seminars. Although offered as supportive events, attendance was not mandatory. The computer literacy workshops, research and grant writing workshops and professional development workshops were perceived as the most beneficial. Attending meetings of the Graduate and Professional Scholars association, the peer support organization which sponsored campus tours, Minority Recruitment Day, academic, and social programs, received the lowest rating. A possible explanation is that this particular program was a fairly recent addition to the fellowship program. In fact one respondent made the point that during the 1988-90, programs such as GAPS, special orientation, and tutoring were not available. In addition, out-of-town, departmental internship assignments for fellows in disciplines such as social work made it difficult for them to attend oncampus events.

The present political climate seems intent on eliminating race-based financial assistance supported via public money. Moreover, the current status of historically underrepresented students in higher education reflects a more subtle, but continuing pattern of discrimination (Daniels, 2001). Therefore, it is important to review and document cases where underrepresented students have been successful in attaining their educational and professional goals with the support of this kind of program. The results of this survey indicated that the Patricia Roberts Harris Fellowship program helped the fellows attend graduate school, stay in school and obtain jobs in their fields of interest and was a vital element in accomplishing of these goals. It is important to continue this type of research on other similar fellowship programs, since such programs play a crucial part in the graduate school education of minority students. Regardless of whether a program such as the Patricia Roberts Harris Fellowship is supported by public funds (which is decreasing subject to legal challenges) or private donations, the lesson from our follow-up study is that the recipients of these additional supports rated the program to be of substantial assistance in undertaking and completing their graduate and professional degrees. As access to tax dollars to fund racial and ethnic minority students diminishes, it is increasingly important that alternative sources of support be sought and obtained to continue to enable women and minorities of color to complete higher education in areas where they are poorly represented (e.g., the natural sciences and selected professions). Another lesson is the need to augment other efforts at affirmative action which are less liable to legal challenge, such as proactive, selective, and targeted outreach and student recruitment strategies focused on minority groups (e.g., Oliver \& Brown, 1988; Schiele \& Wilson, 2001; Thyer \& Wilson, 2001).

The political and legal scrutiny of affirmative action programs in higher education is especially intense as evidenced by several recent legal cases including federal lawsuits that challenged affirmative practices at the University of Georgia and University of Michigan. (Wooden v. Board of Regents, 2001, Grutter v. Bollinger, 2003). At the same time, minority students continue to be grossly underrepresented among students earning graduate degrees. While the study here is limited in size and generalizability, it has value in exploring components of a program that minority students perceived to be helpful in their graduate education experience. The study also demonstrates a need for further research on the efficacy of specific components of academic support programs. The fact that fellows rated the program very highly in terms of helping them meet their career goals and attending graduate school and very poorly in terms of helping them with employment and their participation in special seminars and workshops offers possible insight into priorities for such programs. Equally important is the value of research and subsequent inferences that may be drawn related to the experiences and persistence of a group of minority graduate students, a population of students that continues to be grossly underrepresented among graduate degree recipients.

\section{REFERENCES}

Allen, W. R. (1981). Correlates of black student adjustment, achievement and aspirations at a predominantly white southern university. In G.E. Thomas (Ed.). Black students in higher education: Conditions and experiences in the 1970's (pp. 126-141). Westport, CT: Greenwood.

Allen, W. R. (1988). Black students in U.S. higher education: Toward improved access, adjustment and achievement. Urban Review, 20, 165-188.

American Council on Education. (1995-1996). Minorities in higher education. Washington, DC: Author.

Blackwell, J. E.(1987). Mainstreaming the outsiders: The production of Black professionals. New York: General Hall.

Clewell, B.C. \& Ficklen, M. (1986). Improving minority retention in higher education. Princeton, $\mathrm{NJ}$ : 
Educational Testing Service.

Cole, D. (2008). Constructive criticism: The role of student-faculty interactions on African American and Hispanic students educational gains. Journal of College Student Development, 49, 587-605.

Daniels, M. (2001). Horace T. Ward: Desegregation of the University of Georgia, Civil Rights Advocacy, and Jurisprudence. Atlanta: Clark Atlanta University Press.

Daniels, M., Johnson, P. \& Tomlinson, L. (1996). The University of Georgia-Athens Patricia Roberts Harris Fellowships: Minority graduate student support for academic and career success. In C.A. Ford (Eds.). Student retention success models in higher education (pp. 251-260). Tallahassee, FL: CNJ Associates.

Davis, D. J. \& Sutherland, J. (2008). Expanding success through doctoral education: Perspectives from two participants of the Sisters of the Academy research boot camp. Journal of College Student Development, 49, 606-608.

Digest of Education Statistics, (2001) National Center for Education Statistics, U. S. Department of Education, Office of Educational Research and Improvement.

Grier-Reed, Madyun, N. \& Buckley, C. G. (2008). Low Black student retention on a predominantly White campus: Two faculty respond with the African American student network. Journal of College Student Development, 49, 476-485.

Grutter v. Bollinger, No. 2-241. Decided June 23, 2003. 123 S. Ct. 2325. 156 L.Ed. 2d 304.

Hall. M. L. \& Allen, W. R. (1983). Race consciousness \& achievement: Two issues in the study of black graduate/professional students. Integrated Education, 20, 56-61.

Hartnett, R. J (1976). Environments for advanced learning In J. Katz \& R.T. Hartnett (Eds.). Scholars in the making: The development of graduate and professional students (pp. 49-84). Cambridge, MA: Ballinger .

Lehner, J. C. (1980). A Losing Battle: The Decline in Black Participation in Graduate and Professional Education. Washington, DC: National Advisory Committee on Black Higher Education and Black Colleges and Universities, U.S. Department of Education.

Love, B. J.(1993). Issues and problems in the retention of black students in predominantly white institutions of higher learning. Equity and Excellence in Education,
26, 27-36.

McCauley, D. P. (1988). Effects of specific factors on blacks'persistence at a predominantly white university. Journal of College Student Development, 29, 48-51.

Nettles, M. T. (1990). Success in doctoral programs: Experiences of minority \& white students. American Journal of Education, 98, 494-522.

Noel, L., Levitz, R. \& Saluri, D. (1985). Increasing student retention. San Francisco, CA: Jossey-Bass.

Oliver, J. \& Brown, L. B. (1988). The development and implementation of a minority recruitment plan: Process, strategy and results. Journal of Social Work Education, 24, 175-185.

Olson, C., (1988) Recruiting and Retaining Minority Graduate Students: A Systems Perspective. Journal of Negro Education, Vol. 57, No. 1, 31-42.

Palmer, R. T., Davis, R. J. \& Thompson, T. (2010). Theory meets practice: HBCU initiatives that promote academic success among African Americans in STEM. Journal of College Student Development, 51, 440-443.

Palmer, R. \& Gasman, M. (2008). "It takes a village to raise a child": The role of social capital in promoting academic success for African American men at a Black college. Journal of College Student Development, 49, 52-70.

Patterson-Stewart, K.E., Ritchie, M.H., Sanders, E. (1997) Interpersonal Dynamics of African American Persistence in Doctoral Programs at Predominantly White Universities. Journal of College Student Development, 38:5 489-498.

Statistical Abstract of the United States: 2001, $121^{\text {st }}$ Ed , Washington, DC: U.S. Government Bureau of the Census (available http://www.census.gov/compendia/statab/)

Schiele, J. \& Wilson, R. G. (2001). Issues and guidelines for promoting diversity in doctoral social work education. Arete, 25, 53-66.

Thyer, B. A. \& Wilson, R. (2001). Guidelines for recruiting quality doctoral students. Arete, 25, 6-17.

Wilson, R. (1988). Developing leadership: Blacks in graduate and professional schools. Journal of Black Studies, 19, 163-173.

Wooden v. Board of Regents, 247 F. 3d 1262 (2001). 